\title{
АНАЛІЗ РУХУ ТЕПЛОВОЇ ЕНЕРГІЇ В ГЕОТЕХНІЧНИХ СИСТЕМАХ
}

\begin{abstract}
Процеси передачі теплової енергії поширені в природі і охоплюють весь комплекс явищ переносу теплоти в просторі, що обумовлено різницею температур окремих елементів системи. Вони пов'язані 3 різноманітними фізичними явищами, які існують у геотехнічних системах будь-якого рівня, і потребують докладного дослідження.

Ключові слова: теплова енергія, геотехнічна система, теплопередача, конвекція.
\end{abstract}

Процессы передачи тепловой энергии распространены в природе и охватывают весь комплекс явлений переноса теплоты в пространстве, что обусловлено разницей температур отдельных элементов системы. Они связаны с различными физическими явлениями, существующими в геотехнических системах любого уровня, и требуют подробного изучения.

Ключевые слова: тепловая энергия, геотехническая система, теплопередача, конвекция.

Processes of transfer of thermal energy are widespread in the nature and cover all complex of the phenomena of carry of heat in space that is caused by a difference of temperatures of separate elements of system. They are connected with the various physical phenomena existing in geotechnical systems of any level, and demand detailed studying.

Keywords: thermal energy, geotechnical system, a heat transfer, convection.

Теплова енергія геотехнічної системи являє собою сукупність багатьох термічних полів різного походження (рис. 1). Одні 3 них є природними геотермічний градієнт, теплова енергія тектонічних, магматичних, вулканічних та сейсмічних процесів, енергія гідротермальних та флюїдних потоків, тощо, інші антропогенними, як приклад, теплове забруднення від промислових та добувних підприємств, різні відходи, теплі технологічні води, підземна переробка, газифікація, спалювання палива та ін.

Схема 2 частково відбиває велику сукупність чинників теплового балансу геотехнічної системи, їх напрямок, вплив та взаємодію, але вона дає достатнє для первісних досліджень уявлення складності багатокомпонентної системи порушеного масиву гірських порід. Враховуючи багатофазний склад геотехнічної системи, необхідно розділяти механізми передачі теплоти в кожному 3 ii компонентів. Різноманіття термічних процесів у порушеному гірському масиві потребує додаткового аналізу, параметризації та розробки цілісного підходу до прогнозування поведінки системи та розрахунку параметрів, $з$ ціллю управління іiі елементами в складних умовах геотехнічних систем.

Теплопровідність — це молекулярний перенос теплоти в тілах (або між ними), обумовлений неоднорідністю температури в розглянутому просторі. Вона не пов'язана 3 макрорухом тіл i здійснюється передачею енергії від одних мікрочастинок тіла до інших при їхній взаємодії.

(c) Гайдай К.О., Жолудєв С.В., 2011 


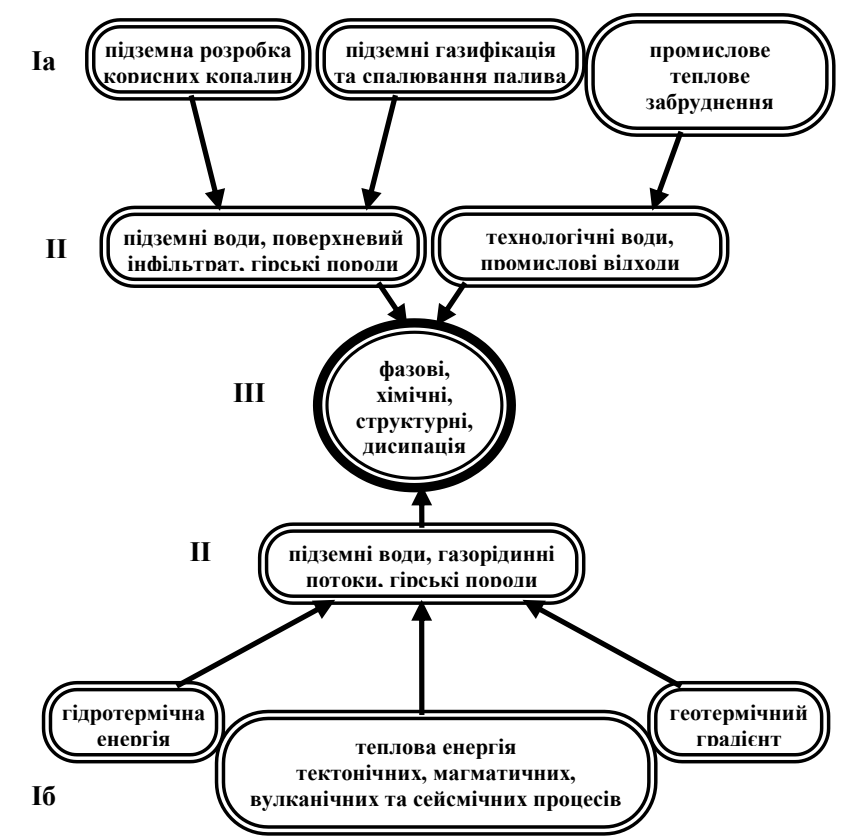

Рис. 1. Схема геотехнічної системи: Іа і Іб - джерела теплової енергії, антропогенні та природні, відповідно; II - шляхи переносу теплової енергії; III перетворення теплової енергії в геотехнічній системі.

Процес теплопровідності в гірських породах, як в твердій компоненті геотехнічної системи, аналогічний процесу електропровідності та пов'язаний 3 рухом вільних електронів. У найпростішому випадку можна вважати, що вільні електрони переміщаються між атомами і здійснюють передачу теплової енергії. Таким чином, процес передачі теплоти визначається дифузією вільних електронів [1].

Перенос теплової енергії рідкою складовою геотехнічної системи, яка головним чином являє собою підземні води в різному стані, здійснюється пружними хвилями. Для газів, що утримуються в системі, він здійснюється молекулами. Молекули більш нагрітої частини газу мають більшу кінетичну енергію в порівнянні з молекулами холодної. При їхньому зіткненні відбувається обмін кінетичною енергією, у результаті чого здійснюється передача теплоти від нагрітої частини до холодної.

Другий тип теплопереносу — конвекція, пов'язаний з переміщенням об'ємів рідини (газу). Конвекція можлива тільки в текучому середовищі, при цьому перенос теплоти нерозривно пов'язаний з переносом самого середовища. У рідинах конвекція завжди супроводжується теплопровідністю. Такий спільний перенос теплоти конвекцією і теплопровідністю називається конвективним теплообміном. Теплообмін між рідиною (газом) i поверхнею твердого тіла називають конвективною тепловіддачею [2].

Третій тип передачі теплової енергії — теплове випромінювання, тобто процес поширення теплоти електромагнітними хвилями. При такому виді передачі відбувається перетворення внутрішньої енергії речовини в енергію випромінювання, перенос випромінювання і його поглинання речовиною.

Теплове випромінювання обумовлене тільки температурою та оптичними властивостями випромінюючого тіла. Воно обумовлено основним законам оптики. 
У чистому вигляді (тобто без інших видів теплообміну) променистий теплообмін має місце лише в умовах глибокого вакууму. У процесах, 3 якими доводиться зіштовхуватися в геотехнічних системах, теплообмін випромінюванням супроводжується конвекцією та теплопровідністю. У цьому випадку теплообмін називають радіаційно-конвективним. Однак його математичне дослідження складне, тому часто попередньо вивчають кожний з видів теплообміну окремо, а потім переходять до розрахунку складного теплообміну. Крім того, при рішенні конкретних завдань один з видів теплопередачі, як правило переважає, і кількість теплоти, яка передана іншими видами теплообміну, незначна i нею можна зневажити.

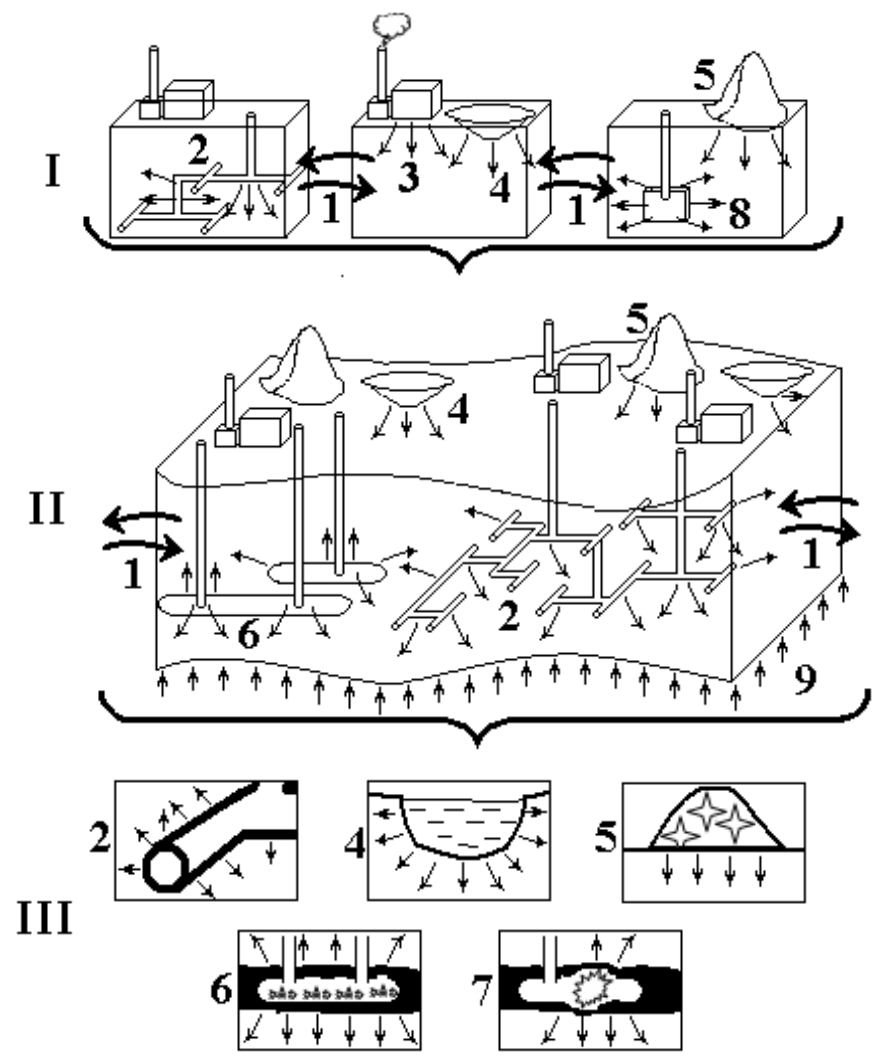

Рис. 2. Схема процесів теплопереносу в геотехнічних системах різного рівня: I, II, III - різні масштаби системи: макро-, мезо- і мікро; 1 - обмін тепловою енергією між різними системами, 2 - підземна розробка корисних копалин, 3 промислове теплове забруднення, 4 - скидання технологічних вод, 5 - терикони та звалища, 6 - підземна газифікація і спалювання вугілля, 7 - підземні ядерні вибухи, 8 - підземні сховища промислових відходів, 9 - тепловий потік 3 надр.

Розглянемо докладніше процес переносу теплоти теплопровідністю. Теплопровідність, здебільшого, поширена у твердих тілах. У рідинах і газах теплота передається конвекцією, тобто чиста теплопровідність можлива лише за умови, що вони абсолютно нерухливі, i повністю виключена можливість виникнення в них конвективних струмів.

При теоретичному дослідженні теплообміну необхідно враховувати середовище, у якій відбувається теплообмін. Всі тіла, у яких розглядаються процеси теплопровідності, будемо умовно вважати суцільними, тобто зневажати 
їхньою дискретною будовою. Такий підхід до дослідження процесів теплообміну взагалі і теплопровідності зокрема правочинний, коли розміри об'єктів дослідження досить великі у порівнянні з відстанями ефективної міжмолекулярної взаємодії [2].

Надалі будемо розглядати лише однорідні суцільні середовища, для яких властивості в різних точках однакові при тих самих значеннях температури і тиску. Розрізняють ізотропні та анізотропні суцільні системи. У перших середовищах фізичні властивості не залежать від напрямку, у других , навпаки, деякі властивості в точці можуть бути функцією напрямку. У геотехнічних системах найчастіше зустрічаються ізотропні тіла.

Крім того, під терміном «суцільне середовище» ми розуміємо не тільки чисті речовини, але і суміші (газові суміші, розчини та ін.). У сумішах різних речовин перенос теплоти теплопровідністю пов'язаний з переносом маси і у загальному випадку визначається не тільки наявністю градієнта температур, але й неоднорідністю розподілу полів інших фізичних величин. Наприклад, неоднорідність поля концентрацій приводить до дифузії речовини та додатковому молекулярному переносу теплоти, який називається дифузійною теплопровідністю (ефект Дюфо). Звичайно перенос теплоти, який обумовлений подібними ефектами, малий і ним можна знехтувати.

Оскільки будь-яке фізичне явище відбувається в просторі і у часі, то його вивчення зводиться до знаходження просторово-тимчасових характеристик величин, що визначають цей процес. Сукупність миттєвих значень фізичної величини на всіх точках розглянутої області називають полем цієї фізичної величини.

У процесах теплопровідності основною фізичною величиною $\epsilon$ температура. Завдання теорії теплопровідності складається в знаходженні поля температур розглянутого об'єкта.

Температура $\epsilon$ величиною скалярною, тому температурне поле також скалярна величина. Наведене вище визначення поля справедливо і для векторних величин, що показують як величину, так і напрямок (сила, швидкість, прискорення i т.п.). Такі поля називають векторними полями фізичних величин, розрізняють стаціонарні та нестаціонарні температурні поля.

Нестаціонарним температурним полем називають поле, температура якого змінюється як у просторі, так із часом, тобто температура є функція простору i часу. Стаціонарним температурним полем називають поле, температура якого в будь-якій його точці не змінюється з часом, тобто $є$ функцією координат. Теплові режими, що характеризуються нестаціонарними температурними полями, називаються несталими. У випадку, коли температурні поля стаціонарні, тепловий режим сталий.

Відповідно до числа просторових координат, від яких залежить температура, температурне поле може бути трьох-, двох- і одномірним. У багатьох завданнях теплопровідності зручніше користуватися не декартовою, а криволінійною системою координат.

Переміщення 3 якої-небудь точки тіла в довільному напрямку супроводжується деякою зміною температури. Якщо нескінченно малим збільшенням просторових координат відповідають нескінченно малі зміни температури, то таке температурне поле називають безперервним. А якщо навпаки - температурне поле розривне. Надалі ми обмежимося розглядом лише безперервних температурних полів. 
Якщо з'єднати точки тіла, що мають однакову температуру, то буде одержана ізотермічна поверхня рівних температур. Ізотермічні поверхні $\epsilon$ поверхнями рівня температурного поля. Якщо температурне поле безперервне, ізотермічні поверхні і ізотермічні лінії для даних температур не перетинаються між собою та не обриваються всередині нього.

Перенос теплоти в тілі за допомогою теплопровідності може здійснюватися тільки при неоднорідному розподілі в ньому температури, тобто необхідною умовою виникнення усередині тіла теплового потоку є відмінний від нуля градієнт температури. Як показує досвід, теплота передається від точок з більшою температурою до точок з меншою, тому тепловий потік на відміну від температури, що є скалярною величиною, має певний напрямок.

Відповідно до припущення Фур'є, тепловий потік через елемент ізотермічної поверхні визначається значенням температурного градієнта в розглянутій точці. Основний закон теплопровідності Фур'є формулюється таким чином: «щільність теплового потоку прямо пропорційна градієнту температури» [3].

Теплопровідність $є$ фізичним параметром і в загальному випадку залежить від температури, тиску та властивостей речовини. Вона чисельно дорівнює кількості теплоти, що проходить в одиницю часу через одиницю ізотермічної поверхні при градієнті температури, рівному одиниці, тобто при перепаді температур в один градус на одиницю довжини нормалі.

Теплопровідність різних речовин змінюється в широкому діапазоні. Для газів і пару значення малі, однак вони збільшуються з підвищенням температури. Зміна тиску практично не впливає на теплопровідність газів, за винятком дуже високих і дуже низьких тисків. Істотно залежить від температури теплопровідність твердих тіл, причому характер іiі зміни багато в чому визначається хімічним складом речовини і його структурою. Особливо це актуально для гірських порід, оскільки на їхню теплопровідність поряд 3 температурою істотний вплив робить пористість. Це пояснюється тим, що теплопровідність пор, які заповнює, газ значно менше, ніж компонентів твердої фази, а для підземних вод - навпаки. Таким чином, теплопровідність гірських порід істотно залежить від вологості. Так само не можна зневажати анізотропністю властивостей шаруватих товщ, де теплопровідність уздовж нашарування може відрізнятися від теплопровідності поперек в 3-4 рази [4].

Конвективний теплообмін це передача теплоти при русі рідини або газу. Він завжди супроводжується теплопровідністю, тому одна із проблем при рішенні завдань конвективного теплообміну це проблема оцінки впливу кожного із двох механізмів передачі теплоти. Визначення внеску теплопровідності і конвекції в загальний процес теплообміну в значній мірі полегшує побудова математичної моделі досліджуваного процесу [5].

Конвективна тепловіддача — це теплообмін між поверхнею твердого тіла і рідиною. Розрахунок процесу тепловіддачі базується на співвідношенні закону Ньютона - Ріхмана, відповідно до якого тепловий потік від рідини до елемента поверхні тіла прямопропорційний площі елемента та різниці температур між поверхнею тіла i температурою рідини. Різниця температур називають температурним напором, а поверхня тіла, через яку передається теплота поверхнею теплообміну або поверхнею, що віддає тепло.

Це дозволяє визначити коефіцієнт тепловіддачі як щільність теплового потоку на границі рідини (газу) і твердого тіла, віднесену до різниці температур поверхні цього тіла і навколишнього середовища. 
У загальному випадку на коефіцієнт тепловіддачі впливають геометричні розміри і форма тіла, температура його поверхні, природа виникнення та режим руху рідини, швидкість, фізичні параметри рідини і багато інших факторів. Коефіцієнт тепловіддачі може бути різним у різних точках поверхні, тому розрізняють середній по поверхні теплообміну та місцевий (локальний) коефіцієнти тепловіддачі. Для спрощення теплових розрахунків звичайно користуються середнім по поверхні коефіцієнтом тепловіддачі.

У теплопереносі можливі обидва види руху рідкої фази: вільне і змушене. Вільне виникає внаслідок різниці густини нагрітих і холодних часток рідини, що перебувають у поле дії сили ваги. Теплообмін при такому виді руху рідини називається вільною (природною) конвекцією. Змушений рух (змушена конвекція) виникає під дією сторонніх збудників (наприклад, насосу, вентилятору, вітру, тощо) [1].

Інтенсивність вільного руху залежить від роду рідини, різниці температур між окремими частками рідини, об'єму простору, у якому протікає процес.

Змушена конвекція в загальному випадку може супроводжуватися вільною конвекцією. Такий теплообмін називають змішаною конвекцією. Можна побачити, що відносний вплив вільної конвекції зростає зі зменшенням швидкості змушеного руху та, навпаки, при більших швидкостях змушеного руху вплив вільної конвекції стає малим.

Великий вплив на процес теплообміну робить режим руху рідини. Він визначає механізм переносу теплоти. При ламінарному режимі перенос теплоти до поверхні тіла (або від неї) здійснюється теплопровідністю і визначається коефіцієнтом теплопровідності рідини. Тому що теплопровідність рідин (газів) невелика, поширення теплоти по всій масі рідини при ламінарному режимі руху відбувається повільно. При турбулентному режимі перенос теплоти в напрямку, нормальному до поверхні тіла, здійснюється як теплопровідністю, так і конвекцією. Інтенсивність переносу теплоти при турбулентному режимі руху рідини в кілька тисяч разів вище, ніж при ламінарному режимі.

Необхідно відзначити, що при турбулентному режимі не вся маса рідини має неупорядкований (хаотичний) характер руху. Завжди на поверхні твердої стінки $є$ шар рідини, у якому внаслідок в'язкості рідини зберігається ламінарний характер.

Велике значення має зміна щільності рідини 3 температурою, що характеризується температурним коефіцієнтом об'ємного розширення. При теоретичних розрахунках використовують лінійні залежності щільності рідини від температури. На тепловіддачу впливає і властивість рідини стискатися, що характеризується коефіцієнтом стиснення (ізотермічне стиснення). Для газованих рідин значення дуже малі, що дозволяють при розрахунках ними знехтувати.

Крім того, реальні рідини мають в'язкість. Між шарами, що рухаються 3 різною швидкістю, завжди виникає сила внутрішнього тертя (дотичне зусилля), що протидіє руху. Сила тертя між шарами, віднесена до одиниці поверхні, відповідно до закону Ньютона, пропорційна градієнту швидкості по нормалі до напрямку руху рідини. В'язкість обумовлює різницю між ідеальною та реальною рідиною. В'язкість газованих рідин, практично не залежить від тиску і зменшується зі збільшенням температури. В'язкість газів зі збільшенням температури і тиску збільшується. Коефіцієнт в'язкості ідеальних газів не залежить від тиску. 
Таким чином, процес конвективного теплообміну характеризується сукупністю гідродинамічних і теплових явищ і може бути описаний системою диференціальних рівнянь, що є основою для математичного моделювання [6].

У загальному випадку вивчення процесів конвективного теплопереносу зводиться до встановлення функціональних залежностей між змінними, що характеризують процес. Встановити зв'язок між основними фізичними параметрами, що визначають досліджуваний процес теплопереносу, досить важко. Це пояснюється тим, що при конвективному теплообміні поля температур і швидкостей тісно взаємозалежні. 3 одного боку, температурне поле рідини, що рухається, багато в чому визначається динамікою плину, тобто залежить від поля швидкостей i його змін. 3 іншого боку, теплофізичні властивості рідини (насамперед в'язкість) істотно залежать від температури, що, у свою чергу, викликає зміну в полі швидкостей.

Конвективний теплоперенос описується за допомогою основних законів збереження маси, кількості руху та енергії. Закони збереження застосовують до виділеного елементарного об'єму, через границі якого протягом малого проміжку часу переносяться певні маса, кількість руху й енергія, що змінюються усередині цього об'єму. Інтегрування складених у такий спосіб диференціальних рівнянь дозволяє визначити залежність між шуканими величинами для всієї області інтегрування й розглянутого проміжку часу.

Оскільки теплопередача в рідинах розглядається як для суцільного середовища, то теоретичне вивчення конвективного теплообміну зводиться до визначення залежностей для поля швидкостей, тиску, температури та фізичних властивостей [7].

Основні диференціальні рівняння, що описують процес конвективного теплообміну, виведені з узагальненого рівняння переносу субстанції, що визначає перенос маси, імпульсу, енергії, тощо, у суцільному середовищі, що рухається.

Крім того, для повної визначеності завдань конвективного теплообміну систему диференціальних рівнянь необхідно доповнити умовами однозначності. Ці умови дають математичний опис всіх особливостей досліджуваного процесу. Умови однозначності включають: 1) геометричні, що характеризують форму і розміри області, у якій проходить досліджуваний процес теплообміну; 2) фізичні, що характеризують теплофізичні властивості середовища і тіла; 3) початкові, що характеризують процес у початковий момент часу (якщо процес стаціонарний, ці умови відпадають); 4) граничні, що характеризують особливості протікання процесу на границях області [8]. Таким чином, математичний опис процесів конвективного теплообміну складається 3 рівнянь руху, нерозривності, енергії, тепловіддачі та умов однозначності. У ряді випадків у цю систему включають додаткові співвідношення (рівняння стану та інші).

\section{Бібліографічні посилання}

1. Беляев Н.М. Основы теплопередачи. - К.: Вища школа, 1989. - 343 с.

2. Беляев Н.М. Термодинамика: Учебное пособие. - К.: Вища школа, 1987. $344 \mathrm{c}$.

3. Лейбензон Л.С. Собрание трудов: В 4 т./ АН СССР. - М., 1953. - Т. 2: Подземная гидрогазодинамика. $-544 \mathrm{c}$.

4. Варгафтик Н. Б. Справочник по теплофизическим свойствам газов и жидкостей. - М.: Изд. Физ.- мат. лит. , 1963. - 708 с. 
5. Беляев Н.М., Рядно А.А. Математические методы теплопроводности: Учебное пособие. - К.: Вища школа, 1992. - 415 с.

6. Гидродинамика и теплообмен в одно- и двухфазных потоках/ Под. ред. Щукина Л. Н./Труды Московского энергетического института, №131. - М.: Изд. МЭИ, 1986. - 162 с.

7. Бутузова Л.Ф., Саранчук З.И., Буравцова О.А., Шендрик. Роль воды в процессах термической и термоокислительной деструкции/ Геотехнологические проблемы топливно-энергетических ресурсов Украины. - К.: Наукова думка, 1985. - с. 107-113.

8. Интерсолл Л. Р., Зобель О. Дж., Интерсолл А. К. Теплопроводность, ее применение в технике и геологии: Пер. с англ. - М.: Изд. маш. лит., 1959. $259 \mathrm{c}$.

Надійшла до редколегії 14.03.11 